\title{
Parenting in low-income families from the perspective of social work
}

\author{
A. Banovcinova*, E. Mydlikova, and M. Vodicková \\ Trnava University, Trnava, Slovakia
}

\begin{abstract}
The family is the primary socializing factor. Its mission is to create a stable and safe environment for the child and for his comprehensive development. The role of parents is to give to a child the values and norms accepted in the society, which is a prerequisite for successful integration of a child into society. That is why the upbringing function of the family is regarded as one of the main. This feature is, however, influenced by many factors.

The goal of the study was to find how poverty affects parenting. For the data collection was used questionnaire Alabama Parenting Questionnaire (APQ), which measures parenthood through five dimensions (1) positive involvement with children, (2) Supervision and monitoring, (3) use of positive discipline techniques, (4) consistency in Theus of discipline chniques, (5) use of corporal punishment. The sample was divided into two groups, with the first group consisted of 188 parents living in poverty The reference group consisted of parents living in households with income standard ( $\mathrm{N}-188)$. Analysis of the results showed differences between parents living in poverty and between parents with a standard rate of income especially in monitoring and supervision, and also in the use of positive disciplinary techniques. On the contrary, there were no significant differences in cooperation between the parents or the use of corporal punishment. Based on the results it is clear that poverty is one of the factors affecting parenting. Therefore, social worker who works with lowincome families should focus attention on this area of family functioning.
\end{abstract}

\section{Introduction}

Poverty in contemporary society is increasingly widespread problem. The number of lowincome families continues to grow. According to statistics from the Central Office of Labour, Social Affairs and Family in December 2016, families with dependent children accounted for $35.38 \%$ of the total number of recipients of social assistance benefits [1].

Mydlíková [2] notes that the most common area where there is a disruption of the functioning of the family is the economic function. Although the disorder (dysfunction) manifesting in the disruption of economic functions normally respond to social therapy efficiently and rapidly, the danger is that the disorder typically trigger malfunction in other functions.

\footnotetext{
${ }^{*}$ Corresponding author: banovcinova.aegmail.com
} 
A life of poverty and poor socio-economic situation of the family causes detriment to a child, not only through inadequate meeting his needs due to lack of funds, but also through the influence of parents. Parents play the most important role in the socialization of the child. Through them, the child learns the norms and values preferred within the particular society, accepted patterns of behavior and builds self-regulating mechanisms. Also Backmen and Ferrarini [3] point at the risk of child poverty and the need to tackle this problem. They consider child poverty a more serious problem than adult poverty because children are unable to control it. According to the aforementioned authors, a period of childhood spent in poverty has serious implications for the future development. The risk of social exclusion and poverty in the adulthood to some extent begins to manifest in childhood, when the cognitive abilities are formed. Child poverty is influenced by three main factors, namely the family, the labor market and the state. Main family factors include parents' education, their average age, the number of children in the family, child living with one or both parents.

Barnett, Corwyn and Bradley [4] draw attention to the impact of stress, which is part of everyday life of families with low socio-economic status. Even for adult family members, a bad economic situation is so stressful that affects their mental and health condition, which results in impaired childcare. Parents who tend to make do with whatever funds are often emotionally unprepared to provide necessary support to children. Low family income, poor living conditions, lack of access to services and opportunities, and a lack of common children's activities cause various negative impacts on children's lives [5].

Long-term living in poverty affects all areas of a child's life. Several studies have demonstrated the negative impact of low socioeconomic status families on child's physical development and health. The research carried out by Currie and Stabile [6] showed that children from families that can be classified as poor have on average lower birth weight and higher infant mortality risk. Duncan et al. [7] investigated the effect of economically disadvantaged environments on children's behavior. Their research indicates that these children are more frequently diagnosed with behavioral disorders. Roos, Nair, Deng and Burrell [8] found that children coming from low-income families have a higher likelihood of health problems, which manifest themselves in the first year of age compared to children from wealthy families. Their health condition is caused by insufficient and inadequate diet.

In addition to the physical and health conditions, life in the family at risk of poverty also impact social functioning of the child. Roos, Nair, Deng and Burrell [8] found that longterm poverty increases the probability of nonconformity in children, resulting in problems of dealing with the difficult situation in adolescence. In economically disadvantaged families, parents seldom appreciate developmental achievements and abilities of their children. They communicate a little with children, and there are noticeably large differences in quality content and form of communication. Mothers with low socio-economic status tend to be in education of their children more direct, closer and use punishment more frequently. They rarely spend their free time together with children [4].

Inability of parents to ensure the child enough incentives for all-round development due to insufficient resources is often reflected in the school results of the child.

Family income belongs to the most important factors that influence the success in school. These children suffering from poverty in preschool and school periods tend to have a lower successfulness in school as compared to children and adolescents who have experienced poverty later or never. Economic pressure in the families with adolescents can lead to a deepening division with parents [9]. Research of Hart and Risley [10] has shown that children coming from families who are dependent on social benefits can hear during the first three years of their life one million words from their parents as compared with children coming from families with a standard income. These children can hear during these years up to thirty million words from their parents, which is reflected in building of 
their vocabulary. Language plays one of the most important roles in the quality of life, future education and personality development. We are therefore inclined to the view that this issue requires sufficient attention if we want to alter thinking in future exempt from the state of poverty.

Lee and Orfield [11] found that students coming from high-income families have in the test better results than students from low-income families. Furthermore, research has shown that parents of students from high-income families have higher education on the basis of which they are able to pass their acquired knowledge to their children. It was also found that students coming from high-income families have more resources. These children have much easier access to modern facilities for education (eg. computers, toys) or go to preschool which prepare them better for school. On the other hand, students living in lowincome families have lower expectations, aspirations and motivation. Parents and teachers of pupils living in poor families do not have high expectations with the result that poor children are insecure with their abilities and are not motivated to perform educational duties at the required level.

A similar conclusion was reached by Havemen and Wolfe [12], who, in addition, found that children from economically disadvantaged backgrounds have worse school results. After completing the education is more difficult for them to integrate into the labor market [13] and they tend to have more health problems [14]. All these factors have ultimately impact on their job prospects and therefore on individual income levels [15].

We agree with the author Kusá [5], who states that parents who live in poverty have to fight daily for survival of the family and must often sacrifice to protect their offspring from the negative effects of poverty. Hoping to find the most suitable deal for themselves and children, they must often prioritize food and clothing for children. Even so, parents are blamed, in most cases, for not paying enough care to children, even when they try to make the most for them, even though they themselves are in bad living conditions. Since parents are responsible for the quality of life of their kids, parents are usually blamed for their problems. Families go into debt, as parents seek to cover family expenses based on the needs of the family.

\section{Methodology}

It is indisputable that the family is the most important factor contributing to healthy mental and physical development of children. It significantly participates in shaping their personality and is important in building their identities. The quality of relationships between parents and children influences health status and quality of life of the child. If the person copes with adverse life situations a family should create the primary social networks and help him overcome this situation. In pursuit of survival of individuals family environment plays an important role. In order for the family was able to provide its members with optimal conditions for life, it must achieve an adequate degree of functioning in all dimensions and functions. In families living in poverty, there is a failing of economic functions of the family. Research shows, however, that loading of the economic functions of the family affects its functioning in all other areas.

In poor families we are often faced with the presence of stress, which results in depression, anxiety or the wrath of parents, which results in problems in behaviour. Parents who are experiencing such tensions are less sensitive to the needs of their children, which we can observe in the education and care.

The aim of our research was to determine how poverty affects parenting. 


\subsection{Participants}

The sample consisted of 188 respondents living below the poverty line. The condition for inclusion in the survey was being a parent of at least one child younger than 18 years and living with that child in the household (mean age $=37.21 \pm 6.824$, range $=21-60$ ). The second group of respondents formed a reference group consisting of 188 respondents parents of children under 18 living in households with standard income (mean age $=40.63$ \pm 5.840 , range $=27-60$ ).

\subsection{Measures and procedure}

To achieve the objective, we chose a quantitative research strategy. The method of data collection was a questionnaire. To collect data, we used two questionnaires.

The first type was standardized questionnaire Alabama Parenting Questionnaire (APQ), authored by Frick [16]. It consists of 42 closed scaling issues. Our elected questionnaire focuses on measuring five dimensions of parenting: (1) positive involvement with children, (2) supervision and monitoring, (3) use of positive discipline techniques, (4) consistency in the use of such discipline and (5) use of corporal punishment.

The second type was the questionnaire of our own design, which included questions aimed at determining the demographics.

\section{Results}

The results were analysed using statistical software SPSS.

Table 1. Differences in dimensions of parenting.

\begin{tabular}{|c|c|c|c|c|c|c|}
\hline Dimension & Group & $N$ & Mean rank & $U$ & $Z$ & $p$ \\
\hline \multirow{2}{*}{$\begin{array}{l}\text { Positive } \\
\text { involvement with } \\
\text { children }\end{array}$} & Group 1 & 188 & 197.22 & \multirow{2}{*}{16032.500} & \multirow{2}{*}{-1.560} & \multirow{2}{*}{.119} \\
\hline & Group 2 & 188 & 179.78 & & & \\
\hline \multirow{2}{*}{$\begin{array}{l}\text { Supervision and } \\
\text { monitoring }\end{array}$} & Group 1 & 188 & 201.53 & \multirow{2}{*}{15222.000} & \multirow{2}{*}{-2.330} & \multirow{2}{*}{.020} \\
\hline & Group 2 & 188 & 175.47 & & & \\
\hline \multirow{2}{*}{$\begin{array}{l}\text { Use of positive } \\
\text { discipline } \\
\text { techniques }\end{array}$} & Group 1 & 188 & 198.24 & \multirow{2}{*}{15840.500} & \multirow{2}{*}{-1.745} & \multirow{2}{*}{.081} \\
\hline & Group 2 & 188 & 178.76 & & & \\
\hline \multirow{2}{*}{$\begin{array}{l}\text { Consistency in } \\
\text { the use of such } \\
\text { discipline }\end{array}$} & Group 1 & 188 & 199.85 & \multirow{2}{*}{15537.500} & \multirow{2}{*}{-2.037} & \multirow{2}{*}{.042} \\
\hline & Group 2 & 188 & 177.15 & & & \\
\hline \multirow{2}{*}{$\begin{array}{l}\text { Use of corporal } \\
\text { punishment }\end{array}$} & Group 1 & 188 & 183.30 & \multirow{2}{*}{16694.000} & \multirow{2}{*}{-.936} & \multirow{2}{*}{.349} \\
\hline & Group 2 & 188 & 193.70 & & & \\
\hline \multirow{2}{*}{ Total } & Group 1 & 188 & 207.87 & \multirow{2}{*}{14031.000} & \multirow{2}{*}{-3.457} & \multirow{2}{*}{.001} \\
\hline & Group 2 & 188 & 169.13 & & & \\
\hline
\end{tabular}

*Group 1 - income below the poverty line.

Group 2 - standard income. 
Our goal was to see how poverty affects parenting and its various dimensions in your reports. When comparing the groups of respondents living below the subsistence level, with the group of respondents with standard income, we found differences in several dimensions we monitor.

As presented in Table 1, analysis of the results showed significant differences between groups of respondents living in poverty and the group of respondents with a standard income in the dimension of "Supervision and monitoring" $(Z=-2.330, p=0.020)$. Similarly, significant differences between low-income parents and parents with a standard income were shown in the dimension of the "Consistency in the use of dry discipline" $(Z=$ $-2.037, p=0.042$ ). Mann-Whitney test showed significant differences between the two groups of our interest in the total score $(Z=-3.457, p=0.001)$. Analysis of the results did not demonstrate significant differences between the group of respondents living in poverty and the group of respondents with a standard income in the dimension of "Positive involvement with children" $(Z=-1.560, p=0.119)$. There were no significant differences in the dimension of "Use of positive discipline techniques" $(Z=-1.745, p=0.081)$. The last was monitored dimension was "Use of corporal punishment". Even in this dimension, significant differences between the participants living in low-income families and the group of respondents living in families with a standard income were not shown $(Z=-.936, p=$ 0.349 ).

\section{Discussion and conclusion}

Poverty determines the family in many areas and affects its entire functioning. The family is the place where the child is socialized and learns the values and the patterns of behaviour in specific situations. Essential role in this process is played by parents. The aim of our research was to determine how poverty affects parenting and its various dimensions.

The results of the research show us that poverty affects parenting particularly in the dimensions "Supervision and monitoring" and "Consistency in the use of such discipline". Similar results were reached by several authors dealing with the impact of poverty on the behaviour of the parents and the child. McLeod and Shanahan [17] show a correlation between current family poverty and mother's weak emotional responsiveness and frequent use of physical punishment. Similarly Jocson and McLoyd [18] point to the fact that the disorder, parents' distress, and harsh and inconsistent discipline are important pathways that contribute to the development of socio-emotional problems in low-income children across a wide range of ages. Hashima a Amato [19] associate poverty with unsupportive and punitive behavior of parents. Parental interest in child, manifesting through supervision, has a significant impact on his survival and behaviour. Parental indifference adds stress to the child, which is usually often overlooked. Such overlooked children are unable to concentrate, are often anxious, apathetic, aggressive or enclosed in themselves. Up to $65 \%$ of these children had to repeat first grade because the intense stress during this period may result in impairment of the functions of brain centers that affect learning and damage the child's intellect. Children from families where the tension, hatred, and quarrels prevail, may present emotional instability a propensity of jealousy, are often weeping, and also may be hypersensitive and touchy [20]. Lacinova and Škridlikova [21], in turn, mentioned that child from birth responds to the demands of his parents through inborn dispositions and thus provides them with feedback. The parent is able to judge this bond, meaningfully evaluate and change his attitudes and behaviour towards the child. Certainly worth mentioning that, as stated by the authors, in other cases communication between parents and children is usually burdened with stereotypes of certain behaviour. To create a specific process of education, in addition to the child, other influences are also involved, affecting the creation of educational practices, such as parents' previous experience, temperament. 
We agree with the Klimáčková [22], that the needs of children and parents are different to everyone, and timely prevention and support creates long-term benefits for society and the family. It contributes to the prevention of child abuse and neglect caused by wrong approach, ignorance or inability to take care of their children. At the same time the conducted research points to the significance of the first years of life for achieving the quality relationships between parents and children. During this period of child's life, excessive stress, caused by neglecting or bullying parents, destroys his brain development. In connection with disciplinary practices such as requiring discipline of children we must mention the arguments of the author Prekopová [23] suggests that currently the most common cons of upbringing is bossiness of children and that it is often expressed through aggressiveness and defiance. They are reluctant to submit to the requirements of adults and unwilling to accept their authority. Such children seek to manipulate the parents, dictate their conditions and they gain them by force. Finally, it is very important to note the negative aspects of the child and be able to recognize causes of such behaviour. Also Morrish [24] considers a negative impact in the upbringing the lack of defined borders, which has a significant impact on children. Without the establishment of adequate border child is usually rebellious, unmanageable and the parents are frustrated with such a style of upbringing.

An important area of parenting is the application of disciplinary techniques. As we mentioned above, our results showed differences between low-income families and families with standard income in the dimension "Consistency in the use of dry discipline". Pinderhughes et al. [25] indicate that the parent discipline practices are integral in theories of children's socialization. Parents' use of physical punishment with their child is of special interest. Numerous theories posit a role for physical punishment in the development of antisocial behavior in children. According to one set of theories, discipline responses are made in the context of multiple influences ranging from more distal factors such as culture, ethnicity, and socioeconomic status to more proximal factors such as available social supports, family structure, and family processes.

According to Matejček [26], a sentence is what the child perceives as punishment and not how his parents have punished him. Such a feeling is humiliating, unpleasant and even embarrassing, and child would like to avoid it in the future. One of disciplinary techniques is the use of corporal punishment. In this dimension, the impact of poverty has not been demonstrated, that the differences between the two families surveyed were not found. Corporal punishment is engaged in many researches. Gershoff and Bitensky [27] point to the importance of corporal punishment which parents most commonly used in response to the behavior of children who shows signs of aggression. On the other hand, several studies confirm the negative effect in the short term but also in the long term. Corporal punishment against children was included in research in 1999. The survey was made by SLONAD on a sample of 5230 children aged 15-16 years which showed that up to one quarter of those surveyed children experienced physical abuse beatings, kicks even cutting from their parents. One-third of abused children answered that their experiences are still traumatizing and they haven't spoken to anyone about them. The most common forms of domestic violence against children include psychological and physical abuse, verbal abuse, particularly threatening [28].

Living conditions of children in families and communities are, as a result of the increasing workload of parents the stress and the collapse of traditional large families, increasingly demanding, so children often suffer from loneliness. As reported by the Research of Institute of Information and Prognosis in Education in 2005, it was found that $47.3 \%$ of children and more than $56 \%$ of students cannot express their opinion at home due to authoritarian parent. Psychological punishment by parents confirmed $21 \%$ of children and physical punishment $15 \%$. Lack of care, bullying, humiliation, insufficient 
understanding, superior relationship and superficiality were showed, on average, by $6 \%$ of children. Children aged 11-16 were more often physically punished [29] (Správa o mládeži, 2010). Research conducted in the Australia in 2006 Griffith University, Brisbane confirms the association between the violence against children in the family and juvenile delinquency. Negative factors affecting the family-juvenile delinquency include not only beating but also the lack of supervision of parents, harsh and temperamental discipline, child abuse, cold attitude and relationship of parents leading to the neglect of their children. This research found that children who were hurt in childhood did not commit more acts of violence than children who were not hurt. Children who were abused also in the adolescence were more prone to delinquency [22].

Use of positive discipline techniques are also among major disciplinary techniques. Nor in this dimension the differences between families living in poverty and families with a standard income were not confirmed. We are inclined to arguments of a number of psychologists who warn that the use of praise in the upbringing of the child shall be controlled. Excessive praising of children or vice versa little praise affects motivation and achievement of their goals. The purpose of our praise is to encourage the child to continue in anything positive and perform well. If a parent praises wrong, the praise will be counterproductive for him [30]. Between years 2001-2003 empirical research was conducted, examining the issue of remuneration and punishment in the family education in a research sample of secondary school students in our country and the Federal Republic of Germany. Samples were selected into research because of the application different styles of education in these countries. The results of the research show that in German and Slovak families negative educational methods are at the forefront. Parents often order children, prohibit, admonish them or threaten them. They evaluate their children more often when they are guilty of something, and hereby reduce their self-esteem and personal pride. On the other hand, the child's good behavior often remains unnoticed and unappreciated, as parents had taken it for granted [31]. According to Kohn [32], the bulk of compliments intended for children are formed by word reward that affect them as well as many other material rewards. Praising does not represent self-serving tactics by parents. They can easily compliment him on the grounds that they are happy to see what he did. If parents rate their child praising them too often, he will rely on them increasingly and will not learn to make choices and proper judgment. If we look at praise from the psychological point of view, Kopriva et al. [33] perceive praise as superior, power and also manipulative use of some sort of positive comments about the behaviour, properties or activities of the other. At the same time it represents an unbalanced relationship in which the individual feels entitled to evaluate others.

The way parents fulfil their parental role is an important factor affecting the bio-psychosocial functioning of the child. The results suggest that parental accompanying and the development of parenting skills should be an area that emphasized by social worker when working with low-income families.

This paper was prepared as a part of the project VEGA 1/0487/14 Key Concepts of Sesected Systemic Theories in Assesing Riskness of the Families within the Purview of Children Social Protection.

\section{References}

1. Sociálne dávky [online]. http: / /www . upsvar.sk/statistiky/

socialne-veci-statistiky/2016/2016-socialne-

davky.html?page_id=583002(2016) 
2. E. Mydlíková. Vybrane aspekty sociálnej prace s rodinami dlžníkov nájomného. In: Zborník príspevkov: Rizikové súvislosti chudoby a rodiny v súčasnej slovenskej spoločnosti. Ružomberok: VERBUM (2011)

3. M. Magadi, Risks Factors for Severe Child Poverty in the UK. Journal of Social Policy 39, 2,

4. O. Matoušek, H. Pazlarová, Hodnoceni ohroženeho ditěte a rodiny. Praha: Portal, (2010)

5. Z. Kusá, Pre zlepšenie života deti v Europe: vysvetlenie chudoby deti v Europskej unii. Bratislava: Slovenska siet' proti chudobe a Sociologicky ustav SAV (2013)

6. J. Currie, M. Stabile,. Socioeconomic Status and Child Health: Why Is the Relationship Stronger for Older Children? In The American Economic Review 93(5), (2003)

7. G.J. Duncan, J. Brooks-Gunn, P.K. Klebonov, Economic Deprivation and Early Childhood Development. In Child Development 65(2), (1994)

8. M.W. Roosa, S. Deng, R. Nair, G.L. Burrell. Measures for studying poverty in family and child research. Journal of Marriage and Family 67 (2005)

9. J. Brooks-Gunn, G.J. Duncan, The Effect of Poverty on Children. The Future of Children 7, 2 (1997)

10. B. Hart, T. Risley, Meaningful Differences in the Everyday Experience of Young American Children. Baltimore: Paul H. Brookes Publishing Co, (1995)

11. D. Gerbery, I. Lesay, D. Škobla, Kniha o chudobe: Spoločenske suvislosti a verejne politiky. Bratislava: Priatelia Zeme-CEPA (2007)

12. R. Haveman, B. Wolfe, The Determinants of Children's Attainments: A Review of Methods and Findings. In Journal of Economic Literature 33, 4 (1995)

13. P. Gergg, P. Machin, The Relationship Between Childhood Experiences, Subsequent Educational Attainment and Adult Labour Market Performance [online]. http://personal.1se.ac.uk/machin/pdf/lux2000.pdf (1999)

14. A. Currie, M.A. Shields, S.W. Price, Is the Child Health/Family Income Gradient Universal? Evidence from England . Bon: Forschungsinstitut zur Zukunft der Arbeit Institute for the Study of Labor (2004)

15. S.P. Jenkins, T. Siedler, The intergenerational Transmission of Poverty in Industrialized Countries [online]. Berlin: German Institute for Economic Research, (2007)

16. C.A. Essau, S. Sasagawa, P.J. Frick, Psychometric Properties of the Alabama Parenting Questionnaire. Journal of Child and Family Studies 15, No. 5, October (2006)

17. J.D. McLeod, M.J. Shanahan, Poverty, Parenting, and Children's Mental Health. In American Sociological Review 58, No. 3 (1993)

18. R.M. Jocson, V.C. McLoyd, Neighborhood and Housing Disorder, Parenting, and Youth Adjustment in Low-Income Urban Families. In American Journal of Community Psychology 55 (2015)

19. P.Y. Hashima, P.R. Amato, P.R. Poverty, Social Support, and Parental Behavior. In Child Development. 1994. 65, Issue 2 (1994)

20. D. Goleman, Emočni intelignece. Bratislava: Columbus (1997)

21. L. Lacinová, P. Škridlíková, Dost dobři rodiče, aneb, Drobné chyby ve výchově dovoleny. Praha: Portal (2008)

22. A. Klimáčková, Podpora rodičovstva - podpora spoločnosti. Bratislava: Národne centrum pre rovnost' príležitostí (2011)

23. J. Prekopová, Malý tyran. Praha: Portál (2007)

24. R. Morrish, 12 klićưu k di̊sledné výchově. Praha: Portál (2003) 
25. E.E. Pinderhughes, K.A. Dodge, A. Zelli, J.E. Bates, G.S. Pettit, Discipline Responses: Influences of Parents' Socioeconomic Status, Ethnicity, Beliefs About Parenting, Stress, and Cognitive-Emotional Processes. Journal of family psychology: JFP: journal of the Division of Family Psychology of the American Psychological Association (Division 43) 14(3), (2000)

26. Z. Matějček, Po dobrém, nebo po zlém? Praha: Portál (2007)

27. E.T. Gershoff, S.H. Bitensky, The case against corporal punishment of children: Converging evidence from social science research and international human rights law and implications for U.S. public policy. Psychology, Public Policy, and Law 13 (2007)

28. S. Laca, Rodina ako primarne prostredie v spoločnosti, In: Prohuman. [online]. http://www.prohuman.sk/socialna-praca/rodina-akoprimarneprostredie-v-spolocnosti (2016)

29. Správa o mládeži. Národná sprava o štátnej politike vo vzt’ahu k det’om a mládeži v SR. Bratislava: Ministerstvo školstva SR (2010)

30. S. Miklovičová, Chválite svoje deti za všetko? Nerobte to!. [online]. https://eduworld.sk/cd/stanislava-miklovicova/1597/ chvalite-svojedeti-za-vsetkonerobte-to (2016)

31. L. Koldeova, Systém odmien a trestov v kontexte rodinnej výchovy v Slovenskej republike a Nemeckej spolkovej republike. [online]. http://www.pedagogika.eu/kiw_03/artykuly/KiW_3_85-97.pdf (2012)

32. A. Kohn, Five Reasons to Stop Saying “Good Job!” Young Children. [online]. Dostupne: http: / / www . alfiekohn.org/parenting/gj .htm (2001)

33. P. Kopřiva a kol, Respektovat a být respektován. Kroměříž: Spirála (2008) 
